\title{
Penataan Pedagang Kaki Lima, Arus Lalu Lintas Dan Ruang Parkir Di Jalan Teri Kota Tegal
}

\author{
Suprapto Hadi ${ }^{1}$, Riza Phahlevi Marwanto', \\ Brasie Pradana Sela Bunga Riska Ayu ${ }^{3}$,Yogi Oktopianto ${ }^{4}$ \\ 1,2,3,4 Program Studi Manajemen Keselamatan Transportasi Jalan \\ Politeknik Keselamatan Transportasi Jalan \\ Jalan Semeru No.3 Kota Tegal \\ Email: supraptohadi95@gmail.com, riza.phahlevi@pktj.ac.id,
}

yogi.oktopianto@pktj.ac.id

\begin{abstract}
Abstrak
Keberadaan PKL seringkali terabaikan dalam penataan ruang di suatu wilayah. Padahal PKL sendiri memiliki peran penting dalam mendukung perekonomian masyarakat. Daerah Pokanjari merupakan salah satu daerah yang mempunyai jumlah PKL relatif banyak. Hal ini disebabkan posisi sebagai salah satu daerah tujuan wisata kuliner di kota Tegal. Banyak kasus yang mendasari mengenai keberadaan PKL terhadap fungsi tata ruang kota. Di satu sisi, para PKL tetap ingin menjalankan usahanya untuk memenuhi kebutuhan hidupnya sehari- hari dan menunjang perekonomian daerah, tetapi di sisi lain perlu adanya perwujudan penataan fungsi tata ruang kota yang memperhatikan aspek lingkungan secara optimal. Urgensi dari penelitian ini yaitu peneliti ingin memberikan gambaran keadaan kawasan kuliner yang masih berisikan pedagang kaki lima yang berserakan dan juga penataan Kawasan, arus lalu lintas serta ruang parkir. Penelitian ini dilakukan menggunakan metode kuantitatif dimana datadata yang terkumpul dianalisis untuk kemudian diperiksa kesesuaian terhadap kaidahkaidah teknis. Berdasarkan analisis yang dilakukan terhadap kondisi eksisting di dapatkan Pola penataan pedagang kaki lima yang digunakan yaitu sitem zona, sentral wisata dan budaya dengan menerapkan tema kearifan budaya lokal dan penerapan arus satu arah kendaraan yang melalui Jalan Gajah Mada dan Jalan Veteran yang nantinya akan dipertemukan di persimpangan sebagai titik keluar kendaraan serta ruang parkir.
\end{abstract}

Kata Kunci : PKL, Ruang Parkir, Penataan Parkir, Karakteristik Parkir

\section{PENDAHULUAN}

Persoalan Pedagang Kaki Lima (PKL) merupakan persoalan bersama yang harus diselesaikan. Dalam hal ini perlu adanya koordinasi dari pemerintah daerah, para PKL, dan masyarakat sekitar. Daerah Pokanjari merupakan salah satu daerah yang mempunyai jumlah PKL relatif banyak. Hal ini disebabkan posisi sebagai salah satu daerah tujuan wisata kuliner di kota Tegal. Sebagian besar PKL menawarkan berbagai barang dagangan di trotoar sebagai kawasan ruang publik. Berdasar hal tersebut para pejalan kaki telah terenggut haknya untuk berjalan kaki di atas trotoar, karena telah dipenuhi oleh PKL yang menjajakan berbagai barang dagangannya. Trotoar sebagai kawasan ruang publik menjadi hilang fungsinya dengan keberadaan PKL yang berada di sekitarnya. 
Banyak kasus yang mendasari mengenai keberadaan PKL terhadap fungsi tata ruang kota. Di satu sisi, para PKL tetap ingin menjalankan usahanya untuk memenuhi kebutuhan hidupnya sehari- hari dan menunjang perekonomian daerah, tetapi di sisi lain perlu adanya perwujudan penataan fungsi tata ruang kota yang memperhatikan aspek lingkungan secara optimal. Banyak dari PKL mengalami kondisi dilematis. Di satu sisi, mereka ingin berjualan di tempat yang strategis sehingga akan lebih mudah mendapatkan keuntungan, tetapi lokasi strategis tersebut mengganggu fungsi tata ruang kota yang ada, yang berkaitan dengan ketersediaan fasilitas ruang publik yang terganggu. Oleh karena itu dari pihak Pemerintah Daerah berupaya untuk menata keberadaan PKL yang berjualan di sekitar ruang publik.

Urgensi dari penelitian ini yaitu peneliti ingin memberikan gambaran keadaan kawasan kuliner yang masih berisikan pedagang kaki lima yang berserakan dan juga penataan kawasan pedagang kaki lima, arus lalu lintas dan ruang parkir.

\section{LANDASAN TEORI}

\section{Pengertian Pedagang Kaki Lima (PKL)}

Definisi PKL Menurut Karafir dalam Ali dan Syamsu Alam (2012:186): "Bahwa pedagang kaki lima adalah pedagang kecil yang berjualan di suatu tempat umum seperti tepi jalan, taman-taman, emper toko dan pasar pasar tanpa izin usaha dari pemerintah". Bertolak dari penyataan tersebut bahwa pedagang kaki lima adalah mereka yang berusaha di tempat-tempat umum dan tidak mendapat izin dari pemerintah.

\section{Penataan Ruang Pedagang Kaki Lima}

Dalam Peraturan Menteri Dalam Negeri No. 41 tahun 2012 tentang Pedoman Penataan dan Pemberdayaan Pedagang Kaki Lima, dijelaskan bahwa Penataan pedagang kaki lima adalah upaya yang dilakukan oleh pemerintah daerah melalui penetapan lokasi binaan untuk melakukan penetapan, pemindahan, penertiban dan penghapusan lokasi pedagang kaki lima dengan memperhatikan kepentingan umum, sosial, estetika, kesehatan, ekonomi, keamanan, ketertiban, kebersihan lingkungan dan sesuai dengan peraturan perundang-undangan.

\section{Komponen penataan ruang sektor informal, antara lain meliputi:}

\section{Lokasi}

Berdasarkan hasil studi oleh Ir. Geonadi Malang Joedo (1997: 6-3), penentuan lokasi yang diminati oleh sektor informal atau pedagang kaki lima adalah sebagai berikut:

a. Terdapat akumulasi orang yang melakukan kegiatan bersama-sama pada waktu yang relatif sama, sepanjang hari.

b. Berada pada kawasan tertentu yang merupakan pusat-pusat kegiatan perekonomian kota dan pusat non ekonomi perkotaan, tetapi sering dikunjungi dalam jumlah besar.

c. Mempunyai kemudahan untuk terjadi hubungan antara pedagang kaki lima dengan calon pembeli, walaupun dilakukan dalam ruang relatif sempit.

d. Tidak memerlukan ketersediaan fasilitas dan utilitas pelayanan umum.

Mc. Gee dan Yeung (1977:108) menyatakan bahwa PKL beraglomerasi pada simpul-simpul pada jalur pejalan yang lebar dan tempat-tempat yang sering 
dikunjungi orang dalam jumlah besar yang dekat dengan pasar publik, terminal, daerah komersial.

2. Waktu berdagang

Menurut Mc Gee dan Yeung (1977:76) dari penelitian di kota- kota di Asia Tenggara menunjukkan bahwa pola aktivitas PKL menyesuaikan terhadap irama dari ciri kehidupan masyarakat sehari-hari. Penentuan periode waktu kegiatan PKL didasarkan pula atau sesuai dengan perilaku kegiatan formal.

3. Sarana fisik dan jenis dagangan

Sarana fisik perdagangan dan jenis dagangan menurut McGee dan Yeung (1977:82-83) sangat dipengaruhi oleh sifat pelayanan PKL.

a. Jenis Dagangan (McGee dan Yeung; 1977:69).

b. Sarana fisik pedagang kaki lima (Waworoentoe 1973:24)

Masing-masing jenis bentuk sarana berdagang, memiliki ukuran yang berbeda beda, sehingga berbeda pula ukuran ruang yang diperlukan. Besaran ruang mempengaruhi dalam pengaturan dan penataan ruang untuk PKL.

4. Pola penyebaran $\mathrm{PKL}$

Menurut Mc Gee dan Yeung (1977:76) pola penyebaran PKL dipengaruhi oleh aglomerasi dan aksesibilitas.

a. Aglomerasi, aktivitas PKL selalu akan memanfaatkan aktivitas-aktivitas di sek tor formal dan biasanya pusat- pusat perbelanjaan menjadi salah satu daya tarik lokasi sektor informal untuk menarik konsumennya. Adapun cara PKL menarik konsumen dengan cara verjualan berkelompok (aglomerasi). Para PKL cenderung melakukan kerjasana dengan pedagang PKL lainnya yang sama jenis dagangannya atau saling mendukung seperti penjual makanan dan minuman. Pengelompokan PKL juga merupakan salah satu daya tarik bagi konsumen, karena mereka dapat bebas memilih barang atau jasa yang diminati konsumen.

b. Aksesibilitas, para PKL lebih suka berlokasi di sepanjang pinggir jalan utama dan tempat-tempat yang sering dilalui pejalan kaki

c. Menurut Mc.Gee dan Yeung (1977:37-38), pola penyebaran aktivitas PKL, ada dua kategori, yaitu:

d. Pola penyebaran PKL secara mengelompok (focus aglomeration), biasa terjadi pada mulut jalan, disekitar pinggiran pasar umum atau ruang terbuka. Pengelompokkan ini terjadi merupakan suatu pemusatan atau pengelompokan pedagang yang memiliki sifat sama/berkaitan. Pengelompokan pedagang yang sejenis dan saling mempunyai kaitan, akan menguntungkan pedagang, karena mempunyai daya tarik besar terhadap calon pembeli. Aktivitas pedagang dengan pola ini dijumpai pada ruang-ruang terbuka (taman, lapangan, dan lainnya). Biasanya dijumpai pada para pedagang makanan dan minuman.

e. Pola penyebaran memanjang (linier aglomeration), pola penyebaran ini dipengaruhi oleh pola jaringan jalan. Pola penyebaran memanjang ini terjadi di sepanjang/pinggiran jalan utama atau jalan penghubung. Pola ini terjadi berdasarkan pertimbangan kemudahan pencapaian, sehingga mempunyai kesempatan besar untuk mendapatkan konsumen. Jenis komoditi yang biasa diperdagangkan adalah sandang/pakaian, kelontong, jasa reparasi, buahbuahan, rokok/obat- obatan, dan lainlain. 


\section{Penataan Ruang Parkir}

Karakteristik parkir dimaksudkan sebagai sifat-sifat dasar yang memberikan penilaian terhadap pelayanan parkir dan permasalahan parkir yang terjadi pada lokasi penelitian.Berdasarkan karakteristik parkir, akan dapat diketahui kondisi perparkiran yang terjadi pada lokasi penelitian yaitu mencakup antara lain :

\section{a. Volume Parkir}

Volume parkir merupakan jumlah kendaraan yang termasuk dalam beban parkir (yaitu jumlah kendaraan per periode waktu tertentu).

Volume $=\Sigma$ kendaraan yang masuk areal parkir $+\Sigma$ kendaraan yang yang sudah ada.

\section{b. Akumulasi Parkir}

Akumulasi parkir dibutuhkan untuk mengetahui jumlah kendaraan yang parkir pada lahan yang tersedia dengan selang waktu tertentu. Data ini diperoleh dengan cara menghitung kendaraan yang telah menggunakan lahan parker ditambah dengan kendaraan yang masuk dan dikurangi dengan kendaraan yang keluar,maka akan didapat jumlah maksimum dari kendaraan yang parkir pada hari dan waktu tertentu.

\section{c. Kapasitas Ruang Parkir}

Kapasitas Ruang Parkir adalah daya tampung suatu kendaraan pada lokasi parkir. Kapasitas Ruang Parkir dapat dihitung dengan rumus:

Kapasitas Raung Parkir $=\frac{\text { Luas Areal Parkir }}{\text { Satuan Rauang Parkir }}$

\section{d. Kebutuhan Ruang Parkir}

Kebutuhan ruang parkir adalah jumlah tempat yang dibutuhkan untuk menampung kendaraan yang membutuhkan parkir berdasarkan fasilitas dan fungsi dari sebuah tata guna lahan.

$\mathrm{KRP}=\mathrm{JK} \times \mathrm{SRP}$

Keterangan :

$\mathrm{KRP}=$ Kebutuhan ruang parkir

JK $=$ Volume kendaraan parkir pada jam puncak berdasarkan akumulasi

SRP = Satuan Ruang Parkir

Tabel. 1 Satuan Ruang Parkir (SRP)

\begin{tabular}{|l|l|c|}
\hline No & \multicolumn{1}{|c|}{ Jenis Kendaraan } & Satuan Ruang Parkir (M) \\
\hline 1. & a. Mobil penumpang untuk golongan I & $2.30 \times 5.00$ \\
& b. Mobil penumpang untuk golongan II & $2.50 \times 5.00$ \\
& c. Mobil penumpang untuk golongan III & $3.00 \times 5.00$ \\
\hline 2. & Bus / Truk & $3.40 \times 12.50$ \\
\hline 3. & Motor & $0.75 \times 2.00$ \\
\hline
\end{tabular}

Sumber: Direktorat Jendral Perhubungan,1996. 


\section{METODE PENELITIAN}

Penelitian ini dilakukan menggunakan metode kuantitatif dimana data-data yang terkumpul dianalisis untuk kemudian diperiksa kesesuaian terhadap kaidah-kaidah teknis. Secara umum langkah-langkah yang dilakukan dalam penelitian dapat dilihat pada gambar 1 . Metode Penelitian. Data-data masukan berupa hasil survey dan pengamatan dilapangan dijadikan acuan untuk melakukan perumusan pemecahan masalah pada kondisi eksisting.

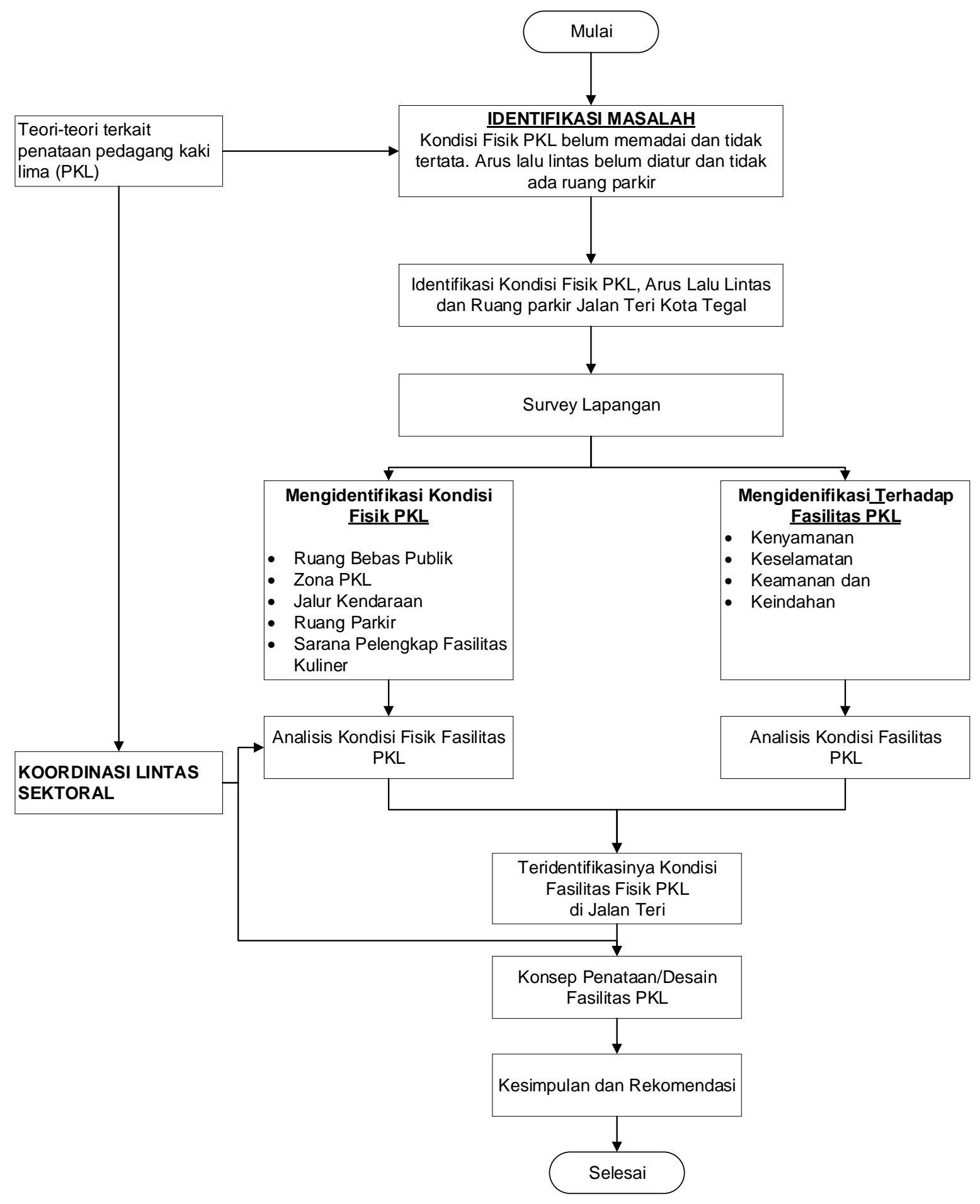

Gambar 1. Metode Penelitian. 


\section{TEKNIK PENGUMPULAN DATA}

1. Data Primer, yakni data yang di peroleh dari:

a. Hasil observasi visual, dilakukan untuk mengetahui kondisi keberadaan PKL di Jalan Teri Kota Tegal.

b. Hasil wawancara, dilakukan pada responden yaitu melibatkan pada institusi/Lembaga yang erat kaitannya dengan Penataan Pedagang Kaki Lima di Kota Tegal, Dinas Koperasi Usaha Mikro Kecil \& Menengah Perindustrian Dan Perdagangan.

2. Data Sekunder, data yang diperoleh dari referensi baik berupa artikel, buku buku serta doumen-dokumen, catatan-catatan, laporan-laporan, maupun arsip-arsip resmi yang diperoleh dari Pemerintah Kota Tegal.

\section{PEMBAHASAN}

\section{Data Teknis Eksisting}

Panjang Jalan $=300 \mathrm{~m}$

Panjang Parkir $=70 \mathrm{~m}$

Lebar Jalan $\quad=5 \mathrm{~m}$

Sebagian besar merupakan warung menggunakan kios permanen . PKL ini menempati sepanjang jalan dan tidak mengikuti pola tertentu.

\section{Penggunaan Lahan}

Penertiban ataupun penataan kota dilakukan oleh pemerintah dalam rangka upaya penataan kota agar tempat-tempat umum terlihat rapi, nyaman, aman dan kondusif sehingga sumua elemen masyarakat dapat menikmati suasana perkotaan yang indahh, nyaman dan aman. Hal ini seringkali berlawanan dengan kepentingan pedagang dalam hal ini pedagang kaki lima (PKL) dimana aspek ekonomi menjadi satu-satunya alasan tempat umum tersebut dijadikan area perdagangan. Tugas dan kewenangan pemerintah adalah menciptakan lingkungan perkotaan yang nyaman, asri dan indah. Pola penataan yang akan diusung pada pusat kuliner Jalan Teri Kota Tegal adalah penataan pedagang kaki lima yang dapat menunjang kinerja ekonomi, sentral wisata dan budaya.

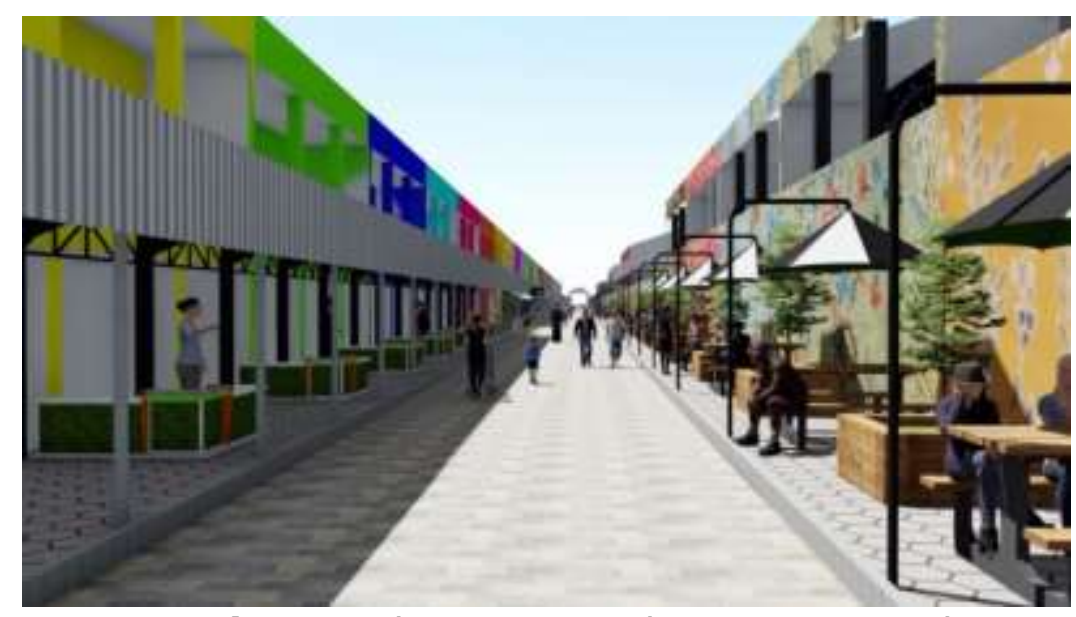

Gambar 2. Pola Penataan Pokanjari Kota Tegal 


\section{Ruang Terbuka}

Pada perencanaan pusat kuliner di Pokanjari Kota Tegal lebih diutamakan area ruang terbuka. Area ruang terbuka berfungsi sebagai tempat-tempat pertemuan dan aktivitas bersama antar manusia. Pada site perancangan, peletakan ruang terbuka publik sesuai dengan eksisting dari pintu masuk sepanjang sisi selatan Jalan Teri.

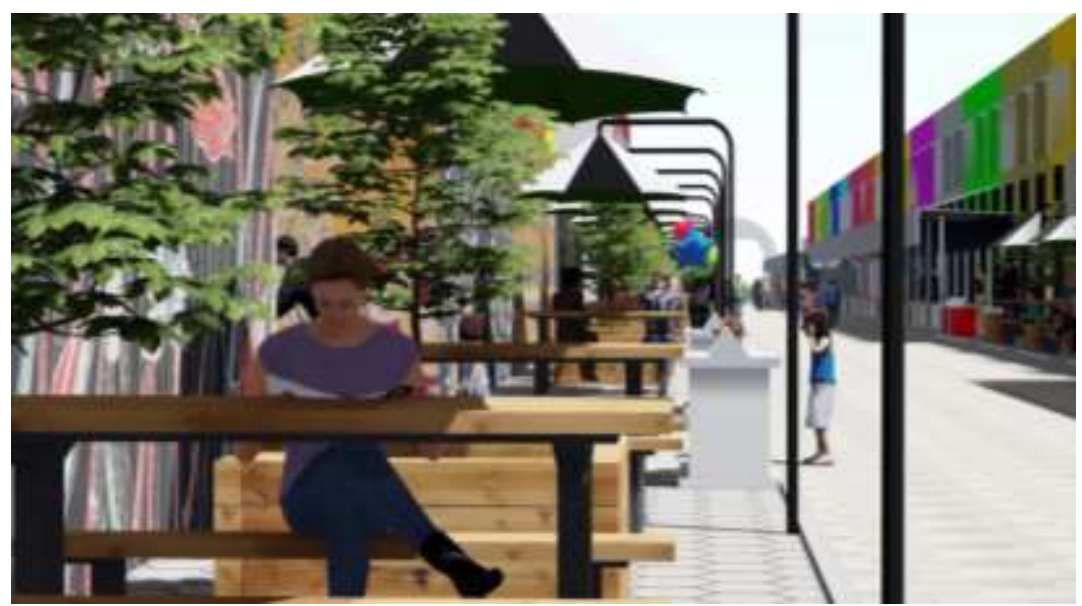

Gambar 3. Ruang Terbuka Publik

Berdasarkan tujuan dibangunnya pusat wisata kuliner di Pokanjari Kota Tegal yaitu sebagai wadah bagi para PKL, sehingga tidak terlihat kumuh oleh dagangan para PKL dan pusat kota akan lebih tertata rapi. Penghadiran kembali konsep ruang terbuka tersebut yaitu dengan memperbanyak bukaan pada setiap kios PKL sehingga sirkulasi udara dapat maksimal dan tidak pengap serta terlihat luas.

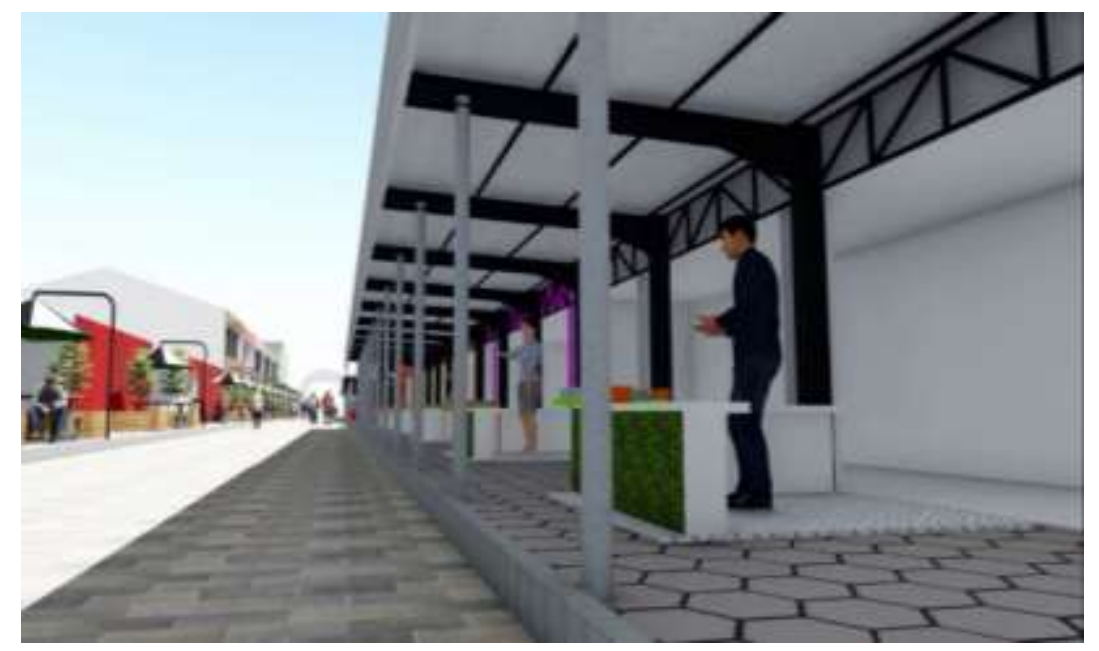

Gambar 4. Ruang Terbuka Kios PKL

Penambahan vegetasi pada area terbuka menjadi unsur tambahan pada ruang terbuka . Vegetasi tersebut berfungsi sebagai peneduh, penghasil oksigen dan pengarah pengunjung untuk menuju ke kios-kios yang ada. Fungsi dari ruang terbuka publik salah satunya yaitu sebagai akses pergerakan orang dan barang dari satu tempat ke tempat yang lain.

Sirkulasi utama pada perancangan pusat wisata kuliner yaitu linear mengikuti site perancangan. Kemudian ditentukan peletakan massa bangunan menurut jenis dagangan dan sarana-nya. 


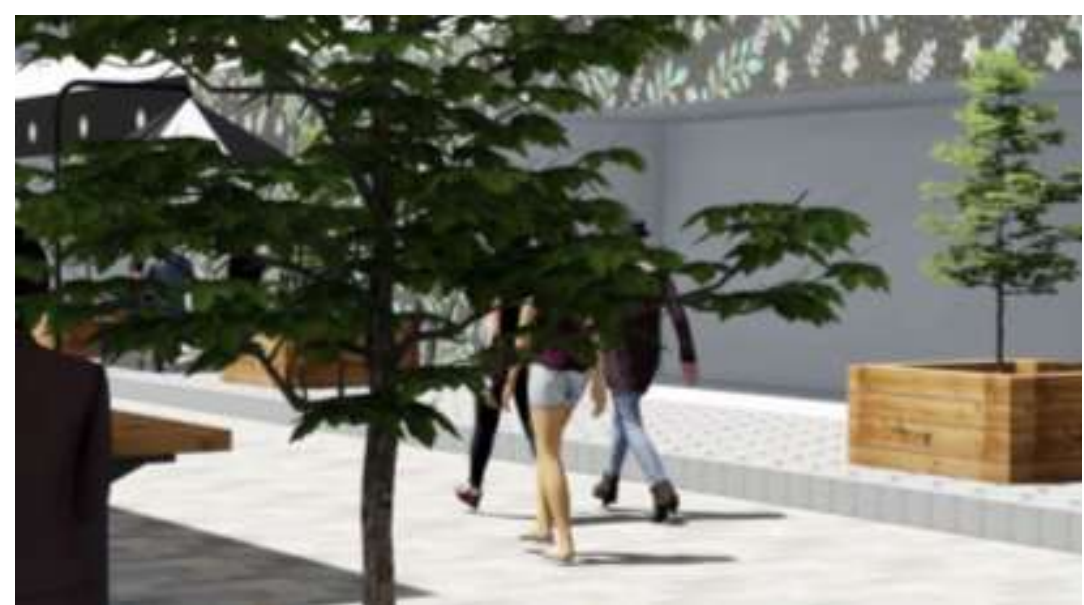

Gambar 5. Penambahan vegetasi Sepanjang Area Terbuka

\section{Pusat Wisata Kuliner}

Pada perencanaan pusat kuliner dengan pemanfaatan ruang terbuka di Pokanjari Kota Tegal lebar bahu jalan pada pusat wisata kuliner yaitu 3 meter. Tempat bagi para pedagang di pusat kuliner dibagi menjadi dengan sistem zona menurut jenis dagangan dan sarana yang digunakan, yaitu makanan ringan, minuman, dan makanan berat. Kios pedagang dan tempat makan dirancang terpisah berseberangan guna mendapatkan kesan luas. Kios pedagang ditempatkan disebelah selatan dan tempat makan diletakan di bagian utara.

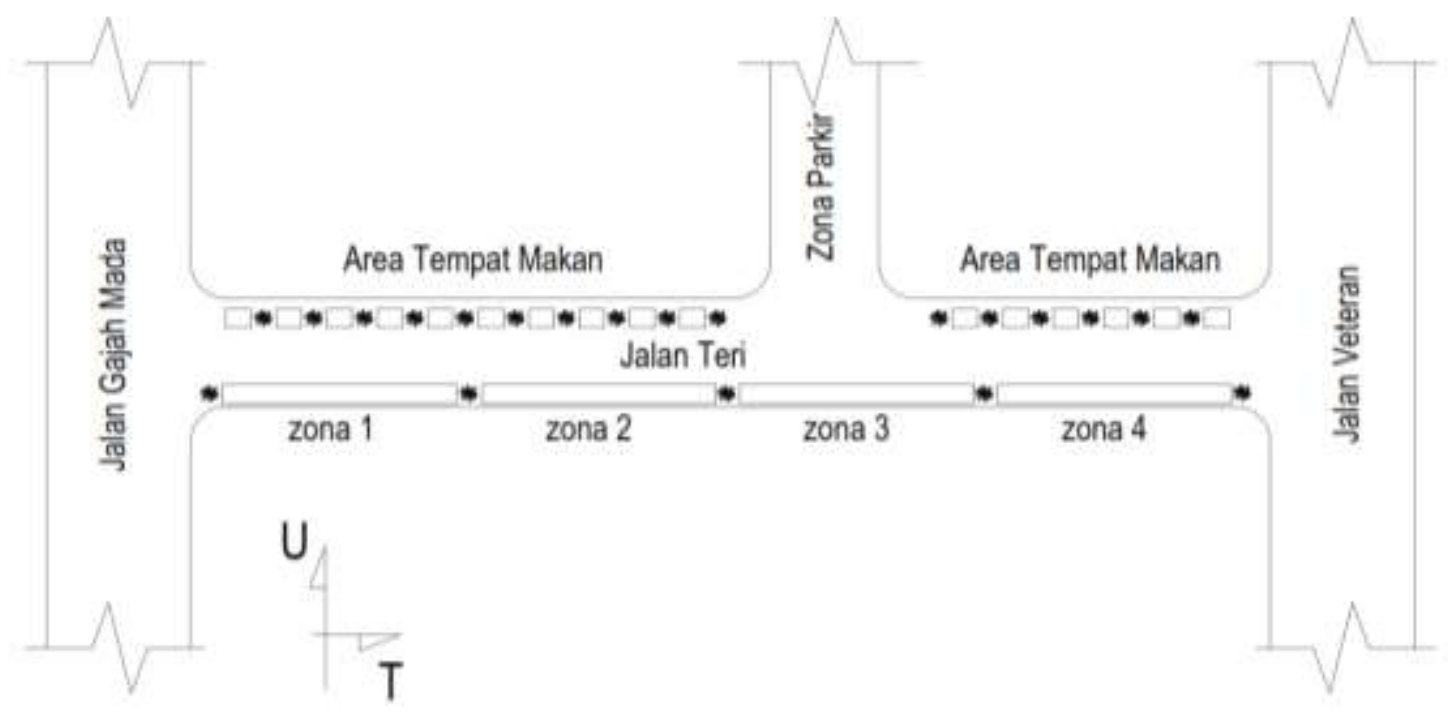

Gambar 6. Plan Penataan PKL Pokanjari

Pusat wisata kuliner di Pokanjari Kota Tegal tidak hanya sebagai tempat makan, minum, dan perdagangan, namun juga memiliki fasilitas panggung terbuka yang berfungsi sebagai tempat atraksi pertunjukkan dan live music. Letak panggung terbuka berada pada area makan disebalah selatan, dengan panggung terbuka sebagai penyatu bangunan permanen area tersebut. Sehingga para pengunjung dapat menikmati sajian makanan sambil melihat pertunjukkan yang ditampilkan atau live music. 


\section{Street Art}

Street Art merupakan salah satu cara mempercantik kota dengan menggunakan seni mural yang cerah dan gambar yang unik. Konsep gang mural atau ruang mural dengan tema kearifan budaya lokal akan dihadirkan pada penataan Pokanjari. Karena gayanya yang unik, mural kini menjadi salah satu cara untuk meningkatkan pariwisata di suatu daerah. Dalam pelaksanaanya akan melibatkan kerja sama muralist lokal.

Walaupun "hanya" jalanan kecil saja, namun beberapa kawasan tersebut akal disulap sedemikian rupa penuh dengan warna dengan mural-mural unik yang tentunya layak buat dikunjungi dan Instagramable untuk menjadi spot berfoto yang akan menjadi sebagai tempat iconic wisata.

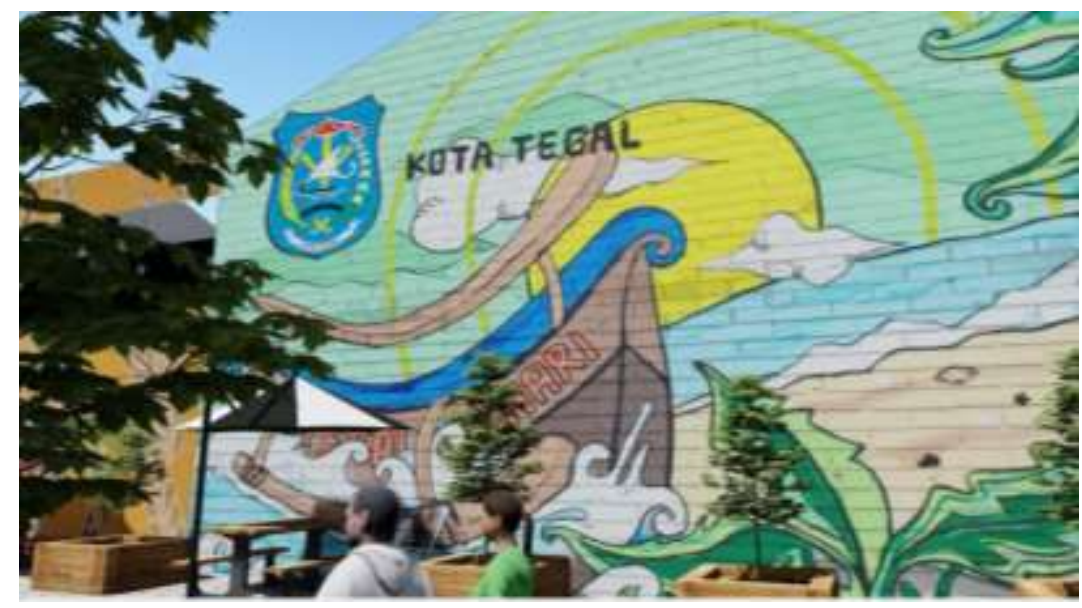

Gambar 7. Street Art

\section{Rainbow Art}

Untuk mendapatkan kesan lain pada kawasan kuliner Pokanjari Kota Tegal selain street art, rainbow art akan dihadirkan di kawasan ini pada bagian selatan yaitu area kios pedagang. Disamping dengan tujuan untuk menjadi kawasan kuliner dan wisata raibow art dihadirkan untuk mempercantik kawasan bangunan lama yang menjadi lokasi eksisting penataan pedang kaki lima Pokanjari. Metode ini dipakai untuk mempertahankan dan tidak merubah kondisi aslinya dengan bermain komposisi warna sehingga bangunanbangunan tua yang menjadi cagar budaya tetap dipertahankan.

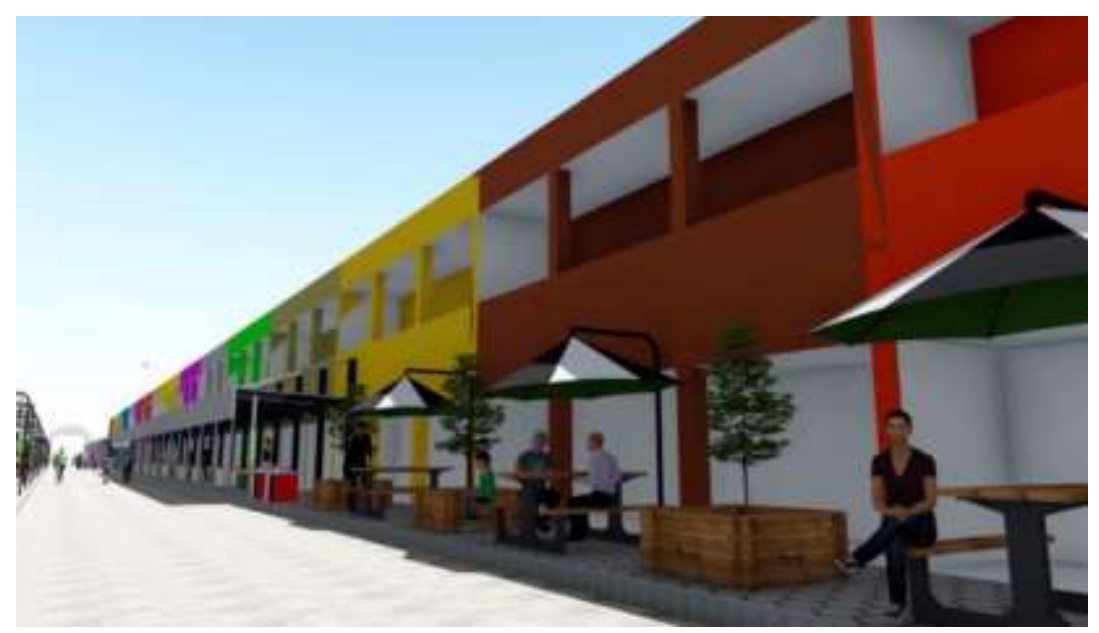

Gambar 8. Rainbow Art 


\section{Kebudayaan Lokal}

Dengan tujuan pariwisata selain menjadi pusat kuliner akan dihadirkan berbagai mural dengan motif batik tegalan. Tidak hanya Sekedar mural biasa, motif-motif batik tegalan akan hadir disini dengan berbagai corak yang disertai dengan nama dan diskripsinya masing-masing. Mural batik yang diaplikasikan selain mempercantik kawasan juga akan menjadi pusat edukasi kebudayaan lokal. Motif yang akan dihadirkan motif klasik maupun motif pengembangan.

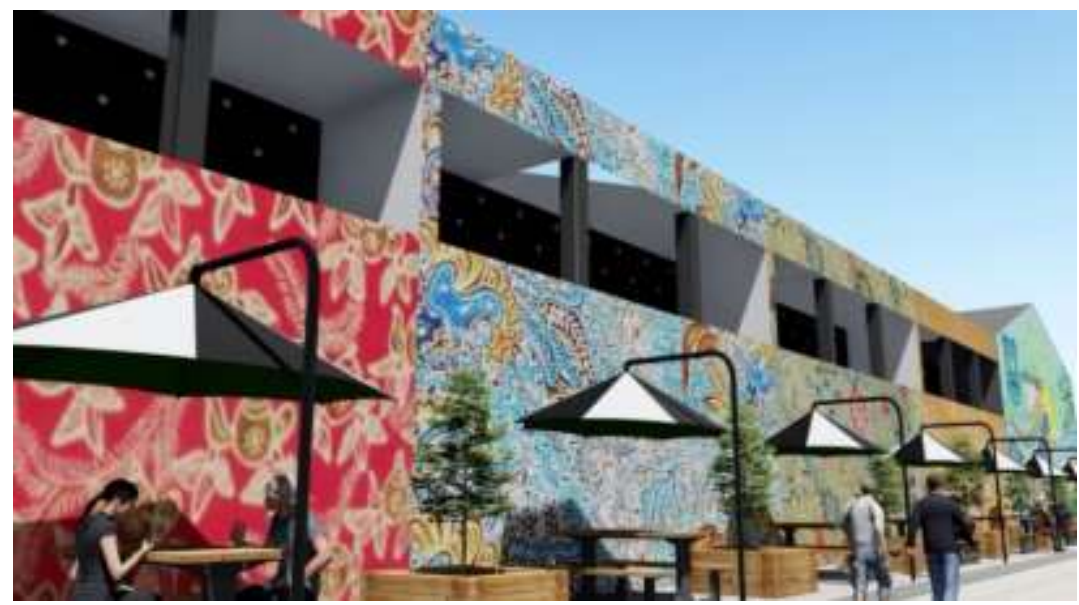

Gambar 9. Kebudayaan Lokal

\section{Keamanan dan Legalitas}

\section{a. Keamanan}

Untuk memaksimalkan tingkan keamanan dan kenyaman pengunjung akan disediakan petugas keaman dan bekerja sama dengan instansi tertentu serta masyarakat setempat.

\section{b. Legalitas}

Legalitas digunakan untuk mengatur pedagang yang berjualan di lokasi yang dilakukan penataan dengan sistem hanya PKL yang terdaftar secara resmi yang bisa berjualan didalam kawasan.

\section{Penataan Arus dan Ruang Parkir}

\section{a. Perencanaan Transportasi dan Distribusi}

Penggunaan transportasi dengan kendaraan bermotor baik sepeda motor, mobil, dll pada saat hari senin, selasa, rabu, jum'at, dan minggu dan pada saat hari kamis dan sabtu tidak diperkenankan kendaraan bermotor melintasi Pokanjari karena untuk memudahkan pengunjung dengan leluasa.

Dengan menyewakan kendaraan tidak bermotor seperti becak dan sepeda untuk memberikan pengetahuan dan melestarikan budaya serta menambah pendapatan.

\section{b. Arus Lalu Lintas}

Dengan menerapkan sistem satu arah yang melalui Jalan Gajah Mada dan Jalan Veteran yang nantinya akan dipertemukan di persimpangan sebagai titik keluar kendaraan serta ruang parkir. 


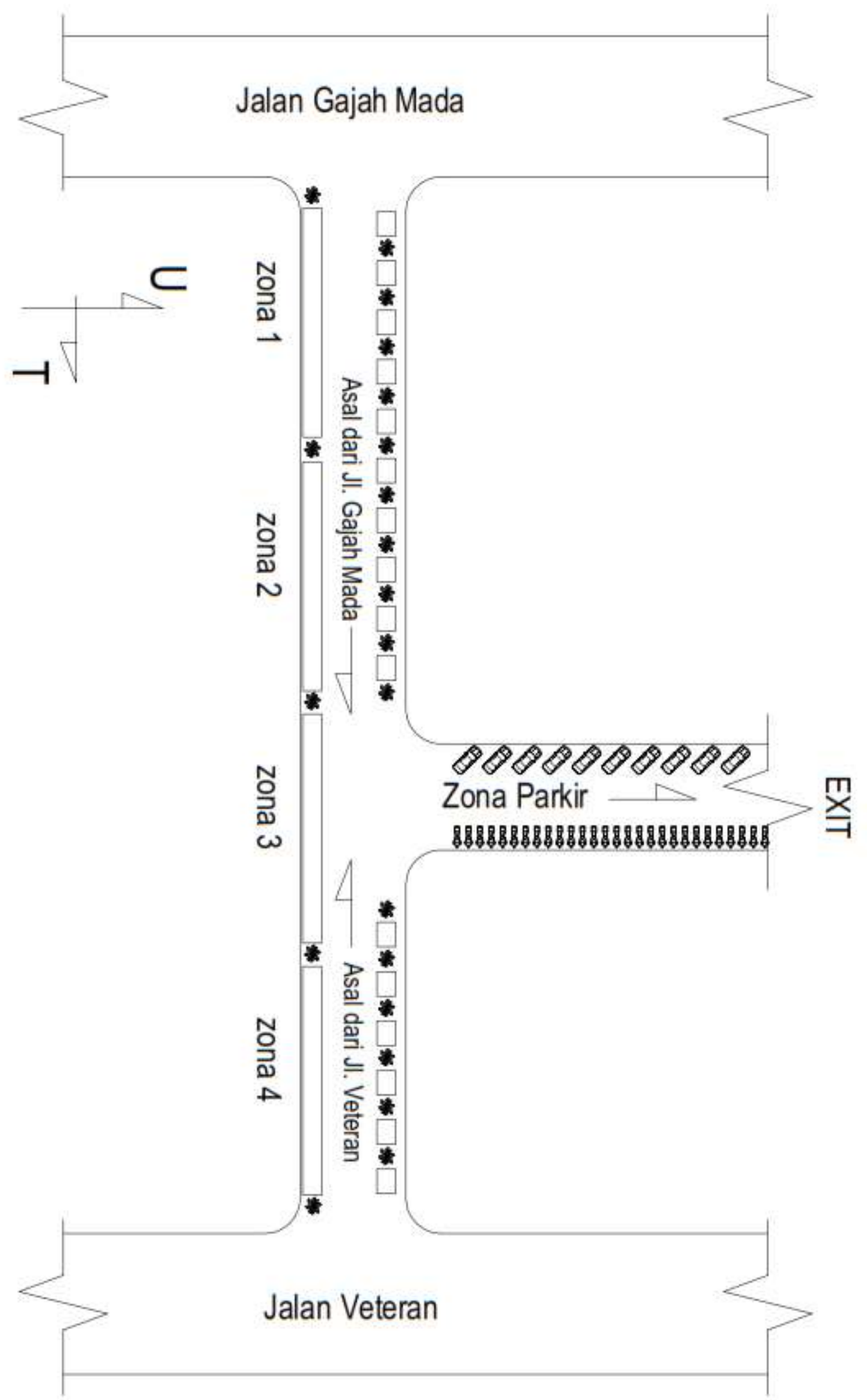

Gambar 10. Plan Penataan Arus Lalu Lintas 


\section{c. Ruang Parkir}

Pusat kuliner di Pokanjari Kota Tegal juga memberikan fasilitas tambahan yaitu dengan menambahkan adanya ruang parkir roda dua dan roda empat yang khusus bagi pengunjung. Fasilitas parkir bagi pengunjung terletak di sebelah utara yang dipusatkan pada satu titik dengan panjang area parkir yang tersedia $70 \mathrm{~m}$. Dengan Panjang lahan yang tersedia dapat menampang kendaraan pengunjung.

\section{a. Kebutuhan Ruang Parkir}

Tabel 2. Kebutuhan Ruang Parkir (KRP)

\begin{tabular}{|l|c|c|c|c|}
\hline $\begin{array}{l}\text { Area Parkir } \\
\text { Kendaraan }\end{array}$ & SRP & $\begin{array}{c}\text { Luas } \\
\text { Efektif }\end{array}$ & JK (Kend) & KRP \\
\hline Motor & 1,5 & 140 & 10 & 15 \\
\hline Mobil & 11,5 & 350 & 7 & 80,5 \\
\hline
\end{tabular}

Tabel 3. Ketersediaan (Supply) Ruang

\begin{tabular}{|l|c|c|c|c|}
\hline $\begin{array}{l}\text { Area Parkir } \\
\text { Kendaraan }\end{array}$ & SRP & $\begin{array}{c}\text { Ketersedian } \\
\text { Lahan } \\
\text { Parkir } \mathbf{( \mathbf { m } ^ { 2 } )}\end{array}$ & $\begin{array}{c}\text { Kebutuhan } \\
\text { Ruang } \\
\text { Parkir }\left(\mathbf{m}^{\mathbf{2}}\right)\end{array}$ & Keterangan \\
\hline Motor & 1,5 & 140 & 15 & Cukup \\
\hline Mobil & 11,5 & 350 & 80,5 & Cukup \\
\hline
\end{tabular}

\section{b. Konfigurasi Parkir}

Konfigurasi areal parkir sepeda motor pada pusat kuliner Jalan Teri Kota Tegal menggunakan pola parkir $90^{\circ}$. Sedangkan konfigurasi areal parkir mobil menggunakan parkir menyudut dengan sudut $45^{\circ}$

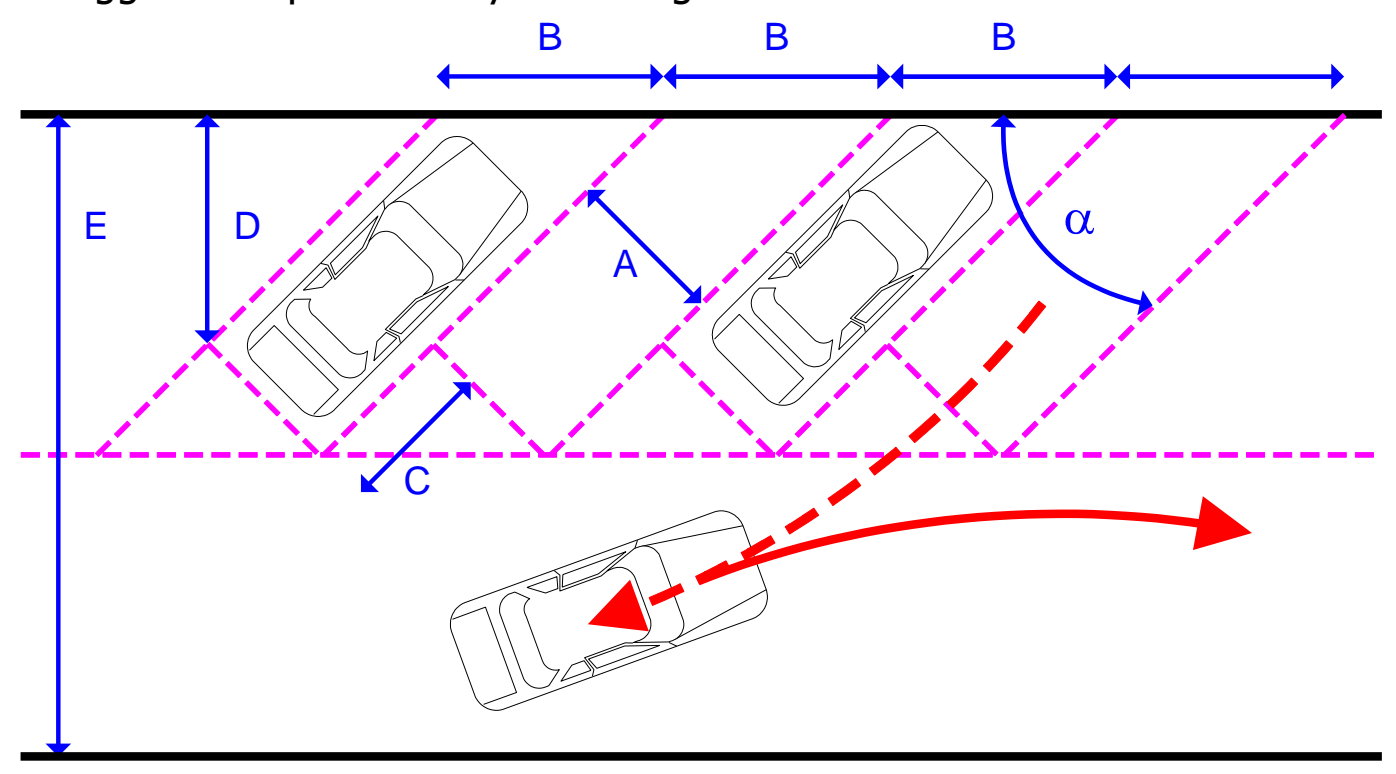

Gambar 11. Konfigurasi Parkir 


\section{Desain 3D Penataan PKL Jalan Teri Kota Tegal}

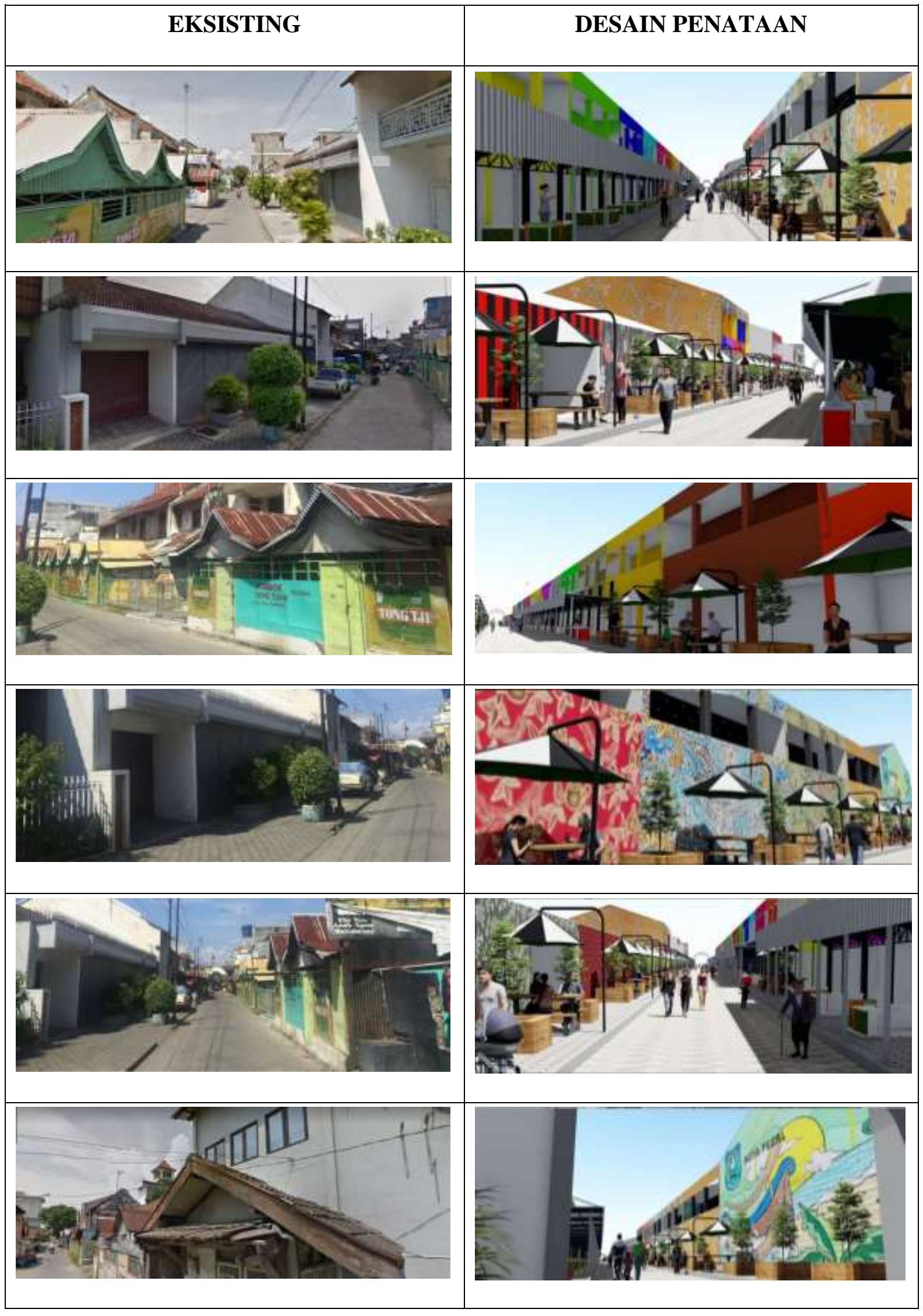




\section{KESIMPULAN}

Berdasarkan analisis yang dilakukan terhadap kondisi eksisting berkaitan dengan penataan pedagang kaki lima, sistem lalu lintas dan manajemen parkir untuk di Jalan Teri Kota Tegal dapat diambil kesimpulan;

1. Pola penataan pedagang kaki lima yang digunakan yaitu sistem zona dengan membagi menurut jenis dagangan dan sarana yang digunakan serta kios pedagang dan tempat makan dirancang terpisah.

2. Hasil desain penataan pedagang kaki lima sebagai sentral wisata dan budaya dengan menerapkan tema kearifan budaya lokal berupa batik tegalan. Motif yang akan dihadirkan motif klasik maupun motif pengembangan yang akan juga menjadi pusat edukasi kebudayaan lokal.

3. Penerapan arus satu arah kendaraan yang melalui Jalan Gajah Mada dan Jalan Veteran yang nantinya akan dipertemukan di persimpangan sebagai titik keluar kendaraan serta penambahan ruang parkir.

\section{SARAN}

Berdasarkan hasil penelitian di atas dibutuhkan penelitian lebih lanjut untuk mengetahui profil pedagang kaki lima (PKL) yang berjualan di Jalan Teri Kota Tegal.

\section{DAFTAR PUSTAKA}

Alisjahbana. 2006. Marginalisasi Sektor Informal Perkotaan. ITS Press: Surabaya

Febrilianawati, Agatha Ika. 2010. Efektivitas Kebijakan Relokasi Pedagang Kaki Lima (PKL) di Jalan Ki Hajar Dewantara Surakarta, UNS: Surakarta

McGee, T.G. \& Yeung, Y.M. 1977. Hawkers in Southeast Asian Cities: planning for the Bazaar Economy. Ottawa: International Development Research Centre.

Nurul.2010.Perlindungan Pedagang Kaki Lima di Indonesia.FKIP: Universitas Negeri Surakata

Parsa, Wayan.(2008). Sanksi paksaan pemerintah dalam penegakan peraturan. Amanna Gappa. Volume 16.

Peraturan menteri dalam negeri Republik Indonesia No 41 tahun 2012 tentang pedoman penataan dan pemberdayaan pedagang kaki lima

Peraturan Daerah Kota Tegal Nomor 3 Tahun 2008 Tentang Pengaturan Pedagang Kaki Lima.

Puspitasari, A, Yuli. 2007. Pengaruh Aktivitas PKL Terhadap Linkage Antara Krato Kasunanan-Ps. Gede Surakarta, Undip: Semarang

Rustopo. 2009. Kebijakan Penataan Sektor Ekonomi Informal di Kota Semarang (Studi Kasus Penataan PKL di Kecamatan Gajah Mungkur).

Sarjono, Yetti. 2006. Pergulatan Pedagang Kaki Lima di Perkotaan. Muhammadiyah Unniversity Press : Surakarta

Saiman, leonardus.(2009). Kewirausahaan (teori, praktek dan kasus). Jakarta: Salemba empat.

Widjajanti, Retno, 2000, "Penataan Fisik Kegiatan PKL Pada Kawasan Komersial di Pusat Kota (Studi Kasus : Simpang Lima Semarang)." Tesis tidak diterbitkan. Bidang Khusus Perencanaan Kota, Program Magister Perencanaan Wilayah dan Kota , ITB, Bandung 